\title{
A Study on the Effects of Emotional Factors on Middle School Students in English Learning
}

\author{
Yuanyuan Zhang \\ School of Foreign Studies, Zhengzhou University of Industrial Technology, Henan 451100, China. \\ 270933844@qq.com
}

Keywords: emotional factors, learning efficiency, influence, teaching techniques.

\begin{abstract}
In the process of modern English teaching, emotional factors have a huge influence on English learning of students. At present, there is a serious segregation between knowledge and emotion for English teaching in China. English teaching focuses too much on cognitive factors of English learning and neglect the influence of emotional factors on English learning. Therefore, it is very necessary to study emotional factors of middle school students to help teachers take different measures according to different emotional features, which is of great significance to improve quality of English teaching in middle school. First of all, this thesis gives a definition and connotation of emotional factor, and then explores the functions of emotional factor. Secondly, this paper focuses on analyzing three kinds of emotional factors that affect learning efficiency of middle school students. These three kinds of emotional factors are confidence, motivation and anxiety. Thirdly, emotional and psychological learning characteristics of middle school students are explored to illustrate influence the emotional factors on English learning for middle school students. Finally, reform strategies on middle school English teaching are proposed. This research studies the emotional factors affecting English learning of middle school students, which will instruct teachers to do English teaching effectively.
\end{abstract}

\section{Introduction}

With the development of globalization, as well as the deepening of reform and opening up, English teaching gradually becomes a focus in the country. There is no denying that domestic English teaching has obtained certain achievement. But there are still many problems and challenges in junior middle school English teaching. There are many negative phenomena for the current English education in junior middle school. These phenomena still puzzle the teachers and students, and teachers' teaching process and students' learning are affected by these phenomena. All these problems are not conducive to social development and harmony. Therefore, studying emotional factors of junior middle school students is very important.

The research purpose is to help English teachers do English teaching better. This research analyzes different emotional factors, such as, confidence, English learning anxiety, and English learning motivation. The research studies the impacts of these emotional factors on English learning for middle school students so that can help teacher's guide English teaching. Researching the influence of emotional factors in English learning satisfies with the psychological requirements of students. English education is to promote the comprehension of students. To achieve the goal we must unite the cognitive and emotional aspects. Therefore, during the process of English learning, teachers should pay attention to students' development of emotional attitudes, meanwhile, teachers ought to infiltrate cultivation of emotional attitudes into teaching English subject, which is conducive to the development of basic education for English language knowledge accumulation and comprehensive ability, but also help students develop positive emotional attitudes. 


\section{Definition and Functions of Emotional Factors}

\subsection{Definition of Emotional Factors}

Emotion is the experience of attitude concerning whether objective things meet individual needs or not. Researchers find that emotional state directly affects learning results of learners. The main emotional factors influencing language learning are confidence, motivation and anxiety.

Emotional factors in language learning can be divided into two categories: one is individual emotional factors which mainly include anxiety, motivation, self-confidence, attitudes and personality; the other is emotional factors between learners and others, which mainly contains empathy, classroom communication and cross-cultural communication.

\subsection{Functions of Emotional Factors}

Positive Emotional factor can arouse the enthusiasm of middle school students, release the learning potential and solve psychological problems in the learning process. Different emotional factors have different effects for improving intelligence. When students put positive emotional factors on English learning, they will become more active to learn English and want to put their passion on English learning, which will be helpful to get high scores in tests. However, when students have negative emotional factors in the process of English learning, they will become passive to learn English and lacking of enthusiasm for English learning, which will be averse to get high score in tests.

Empathetic function refers to that people can transfer their emotions to objects. Empathy is one of the emotional factors of a successful communication. Empathy can make students more involved in class, and help students understand others better. In the usual classroom, the teachers can adopt some useful strategies to cultivate the students' empathetic ability and make students become active and popular communicator when students communicate with others. Emotion can be contagious among people. People can become positive in an optimistic class; otherwise, people will become negative in a pessimistic class. Therefore, emotions of teachers are very significant to students. Emotional states of teachers directly affect students' learning motivation. When teachers have classes; they should keep a positive emotional state.

Emotional factors can adjust learning activities of students. Emotion is able to adjust and influence process of realization. When emotional level of waking gets to the highest point, efficiency of operation will be the most excellent. When emotional level reaches the lowest point, people will be in the condition of sleep. Positive adjusted function can improve efficiency of learning in the process of learning; however, negative adjusted function can delay learning. Emotional factors can motivate students to study happily. Emotion can push or hinder people to join activities. It can strengthen or inhibit the process of development; meanwhile, it can affect directions of development. Dynamic function can muster enthusiasm of learning, which can affect students to do learning willingly. Dynamic function can improve learning.

\section{Emotional and Psychological Learning Characteristics of Middle School Students}

\subsection{Emotional Learning Characteristics}

Middle school is the most influential period during which students change gradually from the hazy and chaos to the clear cognitive concepts and rational judgments. This stage also is the best period for the students to learn language. The part of brain that controls language learning is well-developed, which makes students more sensitive to language.The level of intelligent development for middle school students is basically similar, however, emotional factors influence students' quality of learning to some extent.

\subsubsection{Anxiety in English Learning}

Anxiety refers to the state of emotion which is full of fear and concern. Anxiety includes state anxiety and capacity anxiety. The former indicates the general trend of anxiety in process of learning, and the latter represents the particular anxiety for a specific learning scene. The degree of anxiety affects the result of learning. Students may have a high score because of pressure. But if they are under great pressure, they will get a low score. 
Anxiety produces expectations which make learners want to perform well in English learning. Anxiety hinders learning of language and memory of English and generates the sense of horror to English as well. Foreign language learning anxiety makes students forget what they have learnt and passive in English class. Communicative class teaching approach is an effective way to overcome the emotional anxiety and it can make up for the student's personality defect, then make the introverted students more active to communicate with the extroverted students, which can also relieve the sense of anxiety. Therefore, teachers must pay more attention to student's emotion changes and often encourage students to speak; teachers should create opportunities to guide students and help students overcome shy feeling; teachers need to let the student realize that the process of making mistakes is also the process of progress as well. Everyone makes mistakes. It is unimportant to speak wrongly. It is important to speak out bravely, which is the first step to success. Anxiety in language test is common. Too much anxiety will cause errors in tests. The failure of the previous test will produce anxiety to the next test, for fearing of getting low score during the exam and not living up to the parents and the teacher, when students take the exam, they will be under a lot of pressure, lacking of self-confidence and anxiety.

\subsubsection{Motivation in English Learning}

Motivation refers to learners' psychological reasons to study. Motivations are classified as inner motivations and outer motivations. English learning requires motivation. In outer motivation, family and school have a lot of expectations on students in learning, which pushes students to study hard. In inner motivation, learners study hard willingly.

English learning motivation refers to guide and maintain the students to learn English and make students do learning activities towards a certain goal. Because only do students have positive emotion to himself and English and its culture, students would have a strong motivation to learn English well. Spolsky argues that the motivation of learning English includes three aspects: attitudes, expectations and efforts. [1] These three aspects are a kind of inner need to learn English; the inner need is influenced by many factors, such as interest, confidence, ambition, etc. A survey which is conducted by Qiu Ruijun about objectives of English learning shows that 55\% of the students want to communicate with others; $25 \%$ of the students hope to go abroad in the future; $10 \%$ of the students are to be outstanding students and praised by parents or teachers; $5 \%$ of the students are to satisfy curiosity; $5 \%$ of students do not know the reasons. [2] This survey shows that motivations of learning English have the outer motivation from parents, teachers, etc. The inner motivation of learning English is that the students are curious and thirsty for knowledge at the same time. When learners have motivation to learn English well, they can produce the enthusiasm and initiative of learning, learning activities will change from "let me learn" to "I want to learn". Good learning results also causes a strong achievement motivation, a virtuous cycle is created. Motivation is produced on the basis of the need, and students' psychological development is not perfect.

\subsubsection{Confidence in English Learning}

Confidence refers to degree of acceptance for oneself. Confidence is very important for students to take activities. Meanwhile, confidence determines success of students. Generally speaking, human being has two kinds of sources of confidence. One source is from him, which shows a strong heart and brave mind. The other is from the outer environment, in other words, people become confident when others usually encourage him. Therefore, a sound environment is very significant for this case.

Confident people believe everybody can make mistakes, and making mistakes is not a foolish behavior, they think failure is the mother of success. Not only that, when confident students make attribution of the result, they will contribute the failure to controlling factors that are in-stable, such as effort, they think success is the result of efforts, so after the failure, they get some useful experience to overcome the next challenge and will continue to strive for better results. Confident students in the exam will be not nervous at the same time, they are more likely to perform their normal levels and get good scores. Everyone is eager to success and to be focused on. This phenomenon reflected in the students demands the recognition of teachers and classmates for their own slight progress. Especially now that the majority of children in the rural areas are left behind by their parents, they are more eager 
to be paid attention to. Once their own success is confirmed by others, they will be confident and strive to achieve greater progress. Teachers believe in students; the students would be a little more confident. In fact, it is a process that students confirm themselves.

\subsection{Psychological Characteristics}

Middle school students have strong curiosity. They are curious about everything; therefore, teachers should take advantage of students' curiosity. When giving English lesson, teachers can set interesting questions to arouse students' curiosity. when students are curious and willing to express themselves, they will answer questions actively. However, middle school students have the poorer abilities of understanding, teachers should guide them appropriately. What's more, because of lacking of perseverance, students cannot focus on questions continually. So when teachers set questions to attract students' curiosity, the questions should not be quite difficult.

Middle school students like imitating. They like imitating interesting things. When taking class, they may observe behaviors of teachers and then imitate. Sometimes students may imitate voice of teachers and gestures of teachers, which can enrich class and help them study. This stage of middle school is the golden period of English learning, but students usually are poor in self-control. Therefore, teachers must guide the imitations of students. Their span of concentration is very short; students are exactly difficult to focus on learning for a long time. Imitation can help students improve efficiency of learning. Listening and speaking are very important for beginners. The children in English-speaking countries first listen to others. Then they try to imitate and speak. Students can listen to English programs on radio. You may just understand a few words. It doesn't matter. Just be relaxed, try to catch every word.

Middle school students love games. Playing is the nature of children; therefore, Teachers should not suppress the nature of students but guide them to learn while playing games. Game is not only interesting and knowledgeable for the integration of entertainment, but also an effective way for students to learn. If teachers want to arouse the learning enthusiasm of the students, teachers should help the students get knowledge in the teaching mode of "play in learning, learn in games". [3] Most junior middle school students do not love learning English, students need to expose to English every day, and practice it constantly until they get fun and love English in the end.

\section{Four Emotional Strategies in English Teaching for Middle School Students}

\subsection{Create an Active English Class Atmosphere}

Jane Arnold pointed out, "the total effect of the information is equal to seven percent of writing, thirty-eight percent of pitch and fifty-five percent of facial expressions and gestures".[4] So the teachers' language need to be concise and logical, especially in listening class, teachers' language not only should be refined, but also should affect students. Because listening courses have a lot of input and output, so the students are extremely nervous and anxious. The teachers should convey some concerns of love by a sweet smile and an encouraging look, which will help the junior middle school students feel more comfortable and relaxed. Finally, the teacher can create a good teaching situation. Positive emotional exchanges can promote harmonious classroom atmosphere, stimulate students' interest in learning and mobilize their initiative and enthusiasm. The kind attitude, fluent speaking and standardized handwriting are necessary.

Middle school students start to learn English with a kind of curiosity; they often have a dual attitude in class: on the one hand, they envied teachers, desiring to say a few words by them; on the other hand, they are too ashamed to speak. We strive to make learning free atmosphere, children breath freely in the classroom. The students take an English course every day, the feelings of class directly affects their learning enthusiasm. Lackluster, dull boring, dead-end teaching methods to suppress and kill students' interest in learning. Conversely, pleasant atmosphere, fun language environment, a positive sense of self, will enable students to obtain the maximum amount of languages. At the same time, teachers try to use English in class teaching. From the simplest oral English started initially with appropriate action, emotion or explanation to help students understand. 
After class teachers also encourage the students to say hello to other people in English actively as much as possible, talk about the things around us in English, listen to English songs frequently, and see English movies.

\subsection{Develop Good Relationship}

Traditional teaching methods do not effectively stimulate students' motivation, if the teachers can change their boring teaching methods and meet the reasonable needs of students, which will stimulate students' motivation in English learning. When students trust teachers, they can tell their ideas to teachers. Teachers also can get reliable feedback and guide students to do correct attribution of result, which encourages students to continue to study hard in learning English. Of course, teacher's professional knowledge is an important aspect of attracting students. When teachers have a wealth of knowledge, students will show more admiration to teachers, which is more conducive to develop good relationship between teachers and students. It is not enough to just study hard. You have to know how to study. Good learners find out the best ways to learn well. For example, they may take notes by writing down key words or by drawing mind maps. Good learners also look for ways to review what they have learned. They may do this by reading their notes every day or by explaining the information to another student. The new Curriculum Reform advocates "Student-Centered and Teacher-Led". What is the meaning of the Student-Centered? Most people may say that Student-Centered teaching just means that in the teaching students play the main role rather than teachers. However, Student-Centered teaching is more than that. It's defined as the process of creating the environment while maintaining the control, providing students with interactive activities of the communicative approach as well as conducting students to grasp the knowledge.

\subsection{Establish Encouraging Evaluation System}

Junior middle school students' psychology is mature, when they meet setbacks in learning English; they often need teacher's concern and support. Teachers should use supportive measure in class, for example, teachers should explain some difficult material to students and teachers should also use positive language to guide students to learn English, which can let students experience the sense of achievement of speaking English and enhance the students' self-confidence. If students have positive emotions of learning, they will be calm to face all kinds of difficulties in the process of English learning. In order to mobilize enthusiasm and initiative of students' learning, teachers should try to develop and exert students' positive emotions. So the good effective strategies must be based on superb professional skills of the teachers and good cognitive ability of students. In the process of teaching, teachers should take some responsibility for students' emotion, and provide students with positive effects of language. Teachers should also pay attention to learner's personal emotional factors, and optimize teaching quality from the perspective of emotion. Moreover, teachers must form more practical teaching techniques to help students improve the ability of comprehension. Learners' emotional factors such as learning motivation, anxiety and self-confidence, have a great effect on learners' English learning. Teachers should explore various teaching methods to change the current education mode that is from the teacher-centered to the student-centered. Teachers should also reasonably integrate various emotions in class, which can arouse the learner's sense of curiosity and improve the learners' enthusiasm of participation. Only by doing this, negative impacts of emotional factors will be reduced, and the competence of learners' language learning can be improved, and the best effect of learning can be achieved.

\subsection{Creating Proper Teaching Situations}

If you are interested in something, your brain is more active and it is also easier for you to focus it for a long time. Good learners often connect what they need to learn with something they are interested in. For example, if they need to learn English and they like music or sports, they can listen to English songs or watch sports programs in English. This way they will not get bored. Teaching methods once address the student's field of emotion and will, address the psychological needs of students, this teaching will become highly effective. Psychologists believe that things students are interested in are the easiest to keep in mind. Middle school students are curious, thirst for knowledge, liking imitation, performances, competitions, as well as all new things, unwilling to accept the old 
traditional method of injection, but hope to learn the knowledge in a happy and relaxed atmosphere, So we teachers must create the situations for students .

Situational teaching makes full use of the physical, wall charts, pictures, and environment to create teaching situations, Teachers set a purpose and a specially equipped with the introduction of certain specific emotional color, vivid scenes. If your objects, pictures, slide show, video, the recording of images, storytelling and other forms of material depicting enlightenment, environment rendering, imagination, let students to go to art, to get some experience, stimulate students' emotions in a relatively short time. When students exposure to vivid teaching situation, it helps to stimulate learning emotion, can greatly facilitate the work of the brain, prompting a variety of intellectual factors to play.

\section{Summary}

Emotional factors have important effects on the quality of English teaching. Positive emotions help learners perform well; negative emotions hinder learners to fulfill their potential. English teachers should make efforts to encourage students to participate in actively. So the students cannot only get knowledge and improve the language ability in the learning process, but also complete the task and achieve the goal through the perception, experience, practice, participation and cooperation. Teachers need trying their best to make emotional teaching penetrate in the content of English teaching.

Classroom teaching is an art form, and the students' emotional factors in learning is the key to improve classroom teaching effectiveness and achievement; teachers should make full use of various effective methods to use the positive influence of emotional factors to increase students' learning interest; then classroom teaching can be more effective, efficient and full of fun. However, there is still a long way to go. English teaching well combined with many emotional factors in different aspects. To take advantage of the students' emotional factors in learning is just one of the preconditions to start to learn. Self-awareness, families' cooperation with school, the difficulty level of the teaching material, how hard he or she words and some other aspects, all of which combined organically can pave the way for learning English well.

\section{References}

[1]. Bernard Spolsky. Conditions for Second Language Learning [M]. Shanghai: Shanghai Foreign Language Education Press, 2000, p.55-65.

[2]. Ruijun Qiu, On Positive Role of Affective Factors in English Teaching[J], Journal of Hebei Energy Institute of Vocation and Technology, Vol. 4 (2007), p.88-93.

[3]. Jiahui Gong, Psychology and English Vocabulary Teaching of Students in Junior High School [J], Inquiry in Teaching Method, Vol. 4(2011), p.41.

[4]. Jane Arnold. Affect in Language Learning [M].London: Cambridge University Press, 1998, p.78-88.

[5]. Junge Cui, The Influence of Sensibility in College English Teaching[J], Science \& Technology Information, Vol. 23(2007), p.228.

[6]. Xinyong He, A Survey of Anxiety in Foreign Language Learning [J], Journal of Xuchang University, Vol.31 (2012), p.67-70. 